\title{
A Note on the Privatization of State Enterprises in Ghana
}

\author{
By Joseph R.A. Ayee
}

\section{Introduction}

One of the major economic policy measures taken by Jerry Rawlings' Provisional National Defence Council (PNDC) since coming to power in December 1981, has been the privatization of state enterprises. This policy is part of the International Monetary Fund (IMF) backed Economic Recovery and Structural Adjustment Programmes, aimed at improving the efficiency, profitability and productivity of state enterprises. This article is an effort to assess the effectiveness of privatization as a panacea to the dismal performance of state enterprises in Ghana.

\section{The Concept of Privatization}

The concept of privatization has been defined variously. While some see it as the arrangement whereby a governmental agency that has been producing a service is converted into, or is replace by, a non-govemmental organization 1 ; others perceive it as the process whereby government turns more to private producers for services which government remains responsible and which government continues to finance. 2 In this article, privatization means a broad range of arrangements under which activities once engaged in by govemment are to varying degrees turned over to private hands. 3

Proponents of privatization believe that the public sector is unweildy and that many of the functions currently performed by governments should be better assigned to the private sector directly or indirectly, or left to the play of the market place. It is often argued that the private sector will perform these functions more efficiently and economically than they can

1 Kolderie, T., "The Two Different Concepts of Privatization", Public Administration Review, 46(1986), p. 285-291; Dunleavy, P., "Explaining the Privatization Boom: Public Choice versus Radical Approaches", Public Administration, Vol. 64 (1986), p. 13-34.

2 Butler, S., Privatizing Federal Spending: A Strategy to Eliminate the Budget Deficit, New York, 1985; Savas, E. S., Privatizing the Public Sector: How to Shrink Govemment, Catham, 1985; Shirley, M. M., Managing state owned enterprises, Washington DC (1983): World Bank Staff Working Paper no. 577.

3 Sullivan, $H$. J., "Privatization of Public Services: A Growing Threat to Constitutional Rights", Public Administration Review, 47 (1987), p. 461-467. 
be performed by the public sector. ${ }^{4}$ There is also the belief that the public and private sectors are similar, both being subject to the same set of economic incentives and disincentives. It is held that nearly all public sector activities are potentially amenable to being transferred ot the private sector. The argument is often made by proponents of privatization that private ownership and profitability of a state enterprise are inseparably linked. In the words of Alan Waters:

economic theory is now quite explicit and clear that due to the nature of ownership, and hence incentive, a state entity cannot be as efficient as private entity in the production of the same output. 5

Some scholars have sought to draw a distinction between privatization of provision of public services and the privatization of production. 6 To Kolderie, for instance, provision involves deciding whether a service will be provided at all and if so, "who shall have it an how much of it". 7 Production, on the other hand, is concemed broadly with service delivery, which is defined to include: "operating, delivering, running, doing, selling, administering".8

\section{The PNDC's Justification for Privatization}

Since its assumption of power in December 1981, the Provisional National Defence Council (PNDC), like previous governments before it, has emphasized the profitability criterion as the only yardstick for measuring their viability. In April 1986, Alhaji Idrissu Mahama, the PNDC member responsible for Defence, while addressing officers and men of the Air Force stated that state enterprises "which were expected to bring in revenue but have not, were to blame for the government's inability to service the military and other infrastructure promptly".9

In the Economic Recovery Programme of the govemment, state enterprises have been given certain guidelines in order to make them profit-oriented:

...The govemment has asked all state enterprises to end the irrational pricing policies implied in selling below the break-even point ... The tariff and price increases allowed ... for various commodities and services provided ba the state

4 Moe, R. C., "Exploring the Limits of Privatization", Public Administration Review, 47 (1987), p. 453-460; Butler, op.cit.; Savas, op.cit.

5 Waters, A. R., Privatization: a viable option? Manila: Asian Development Bank, 1985.

6 Butler, op.cit.; Kolderie op.cit.; Savas op.cit.

7 Kolderie, op.cit.

8 Kolderie, op.cit.

9 West Africa 1986, p. 799. 
enterprises reflect the government's policy to make these enterprises financially viable and operationally efficient. 10

This profitability motive has been a major rationale behind the privatization programme. In the words of the Head of Thana's civil Service:

Ghana has chosen the privatization option as a means to revitalize its ailing state enterprises, so that they could operate more purposefully, contribute more to the national budget and generate employment. 11

A corollary reason behind the privatization exercise is the growing government subvention to state enterprises since the coming into power of the PNDC. Government suventions to the enterprises moved from 1.1 billion cedis in 1982 (10 per cent of government expenditure) to 7.35 billion cedis in 1986 (8 per cent of govemment expenditure). In addition, outstanding government loans to the enterprises increased from 500 million cedis in 1980 to 1.9 billion in 1985.12 Virtually no interest or principal repayment is made on these loans. A cross-debt study of some 18 state enterprises undertaken in 1987 has revealed that by june 30th, 1986, the 18 enterprises were indebted to the government to the tune of 400 million cedis, while between themselves 5.2 billion cedis were owed. 13

The PNDC's use of the financial profitability criterion in evaluatin state enterprises calls for two comments. First, scholars have agreed that financial profitability may not necessarily be a good yardstick in measuring the performance of state enterprises. The reason is that the very objective of a state enterprise may be something other than profit.14 A state enterprise may be achieving its objectives by not making a profit, in a country like Ghana, where the public sector plays a direct and dominant role in the development process. In the words of Maniatis:

Besides serving a specific end (e.g. electricity generation), public undertakings are often used as instrument to promote growth, combat regional unemployment, curb inflation, conserve on foreign exchange and so on. 15

The financial profitability criterion does not reflect the social/welfare contribution of a state enterprise. In other words, the fact that a state enterprise has a huge financial surplus does not necessarily mean that it is socially efficient. This is crucial in the case of Ghana because of the following factors:

10 Republic of Ghana, Economic Recovery Programme, 1983-86, Accra, Ghana Publishing Corporation 1983, p. 20-21.

11 West Africa 1985,p. 897.

12 Republic of Ghana, Divestiture Implementation Programme, Accra, Ghana Publishing Corporation 1987 , p. 5.

13 Republic of Ghana 1987, p. 6.

14 Akinsanya, A. "The Former Westem Nigeria Development Corporation: a framework for performance evaluation", Public Administration and Development, vol 1 (1981), p. 25-33.

15 Maniatis, G. C., "Social calculus, profitability and the conduct of public corporations", American Journal of Economics and Sociology, 29 (1970), p. 225-233 (231). 
i. Public enterprises are often called on to undertake activities for which they do not receive financial compensation (e.g. to maintain or expand employment, to incur higher fixed or operating cost by locating plants in disadvantaged regions of the country, etc.);

ii. Public enterprise may still be in its early life (especially if it is engaged in manufacturing activities where a leaming period is required before resources can be efficiently utilised);

iii. The market prices of inputs and goods produced of ten do not reflect their opportunity costs because of taxes, tariffs and quotas on imports an administratively set prices. 16

Second, the PNDC seems to have glossed over other criteria used in the evaluation of corporate performance. Although financial profitability may be a necessary criterion for evaluating state enterprises, it is not a sufficient index. There are other indexes which have been ignored. The economic surplus criterion may be seen as an improvement on the financial surplus criterion in that it seeks to remove the wealnesses of the latter. The economic surplus criterion could be said to be the difference between benefits and cost, measured at accounting prices, that is, at prices that reflect the opportunity costs of both output and the inputs used.17 As a result several adjustments to domestic market prices have to be made to arrive at the economic surplus criterion. This has to do with "shadow pricing". The shadow prices of labour capital, imported inputs of export goods must be taken into account in the measuring of the economic profitability of a state enterprise. There is also the need for the adjustment of govemment - set prices as well as the estimation of the value of the noncommercial activities of a state enterprise. 18

We however, face an uphill task in assessing the true economic cost of benefit of both the commercial and non-commercial objectives of a state enterprise. This is more so when we know that the estimates of shadow prices could be subject to a wide margin of error. ${ }^{19}$ For example, a state enterprise may portray a much higher economic performance at one set of shadow prices than at other set. This does not, however, mean that the cost-efficiency performance of a state enterprise with regard to the commercial and non-commercial objectives cannot be measured.

The other index for measuring the performance of state enterprises is the factor productivity criterion. This is the difference between the rate of growth of output or value added and a weighted average fo the rates of growth of labour and capital stock. The weights, according to Hill, reflect roughly the share of the two inputs in the value of output. 20 The value of

16 Pozen, R., Legal Choices for State Enterprises in the Third World, New York, New York University Press, 1976; Killick, T., Development Economics in Action: A Study of Economic Policies in Ghana, London 1978.

17 Odejide, A. F., "A framework for evaluating the performance of Nigeria public enterprises: implications for privatization" Quarterly Joumal of Administration, XXI 1987.

18 Maniatis, op.cit.; Odejide, op.cit.

19 Hill, H., "State enterprises in a competitive industry: An Indonesian case study", World Development, 10 (1982), p. 1015-1023; Maniatis, op.cit.

20 Hill, op.cit. 
output, however, must be converted into real terms with appropriate "deflators and labour categories of different skills must be aggregated into a total input".21 An account is also taken of capital used per unit of output since productivity could have been raised by adapting a more capital-intensive technique rather than as a result of greater efficiency in using resources. Difficulties are experienced in determining the real quantities of output, labour and capital. In order to forestall some of these difficulties, Hill used what he called "performance indicators".22 These performance indicators include (i) a measure of the efficient use of capital; (ii) the efficient use of equipment alone; and (iii) the distribution of the value-added. By using Hill's performance indicators, we would be able to assess an industry in which the state and private firms are engaged in direct competiton. The factor productivity criterion thus captures more directly the contribution of the state enterprise to growth in income per capita, to the process of leaming and to technical progress than by the economic surplus criterion.

\section{The Privatization Programme}

The PNDC's move towards privatization of state enterprises began in 1982 when it asked a team of World Bank experts to carry out "feasibility" studies on Ghana's state enterprises. The team recommended specific measures such as abolition, elimination, merger and restructuring of the enterprises. On the basis of the report of the World Bank team, the PNDC in 1985 commissioned the United Nations Development Programme (UNDP) and Gnana's Management, Development and Productivity Institute (MDPI) to reassess the enterprises sector as a whole. The team presented its report to the PNDC in June 1986. It recommended the privatization of over 100 state enterprises in phases and the establishment of a 13-member diverstiture Implementation Committee (DIC) to oversee the entire diverstiture programme. In order to strengthen the programme, the PNDC elevated the post of chairman of the State Enterprises Commission (SEC) to the status of a PNDC Secretary (minister). The DIC has a technical committee made up of 5 members of the SEC, one each from the Ministry of Industries, the Trade Union Congress (TUC), the Land Valuation Board, the Ghana Investment Center, the Attomey General's Department and the Committee for the Defence of the Revolution (CDR) secretariat.

Seven types of ownership have been identified in the privatization programme. They are the sale of all or part of the shares to the general public; outright sale or liquidation; joint ventureship (the transfer of part of the state ownership to local or foreign partners); worker share-holding, which envisages the sale of some shares to workers as a unit or to the TUC; community shareholding, that is the sale of shares to a community, which the privatization

21 Odejide, op.cit., p. 199.

22 Hill, op.cit. 
programme referred to us "the original owners of the land"; and institutional shareholding, which is the sale of all part of the shares to institutions, such as banks. 23

The first phase of the privatization exercise involves 32 enterprises, 17 of which were confiscated, during the Armed Forces Revolutionary Council (AFRC) interregnum of 1979, from local and foreign businessmen who had committed "acts of economic sabotage" like under-invoicing, over-invoicing and non-payment of tax. these include the Ghamot and G.E. Amuah group of companies, which operated as exporters and importers of chattels, Overseas Knitwear, Famekwa Trading and Metalico Company and Two Worlds Victory Industries, engaged in wholesale and retail trade. The remaining 15 enterprises are either state owned ones like the State Fishing Corporation, State Farms, Ghana Sugar Estates, Food Production Corporation of joint-venture enterprises, like Neoplan Company, Willowbrook and Kwahu Diary Farms. 24

\section{An Assessment of the Privatization Option}

The PNDC's privatization policy seems to have been influenced by three factors. First, the United State's government's plan to sell public land and transportation companies, such as Conrail and Prime Minister Margaret Thatcher's intention to denationalize the British telecommunication system and British Airways have been used as proof that the economic assumptions of privatization are perfect. Second, experience of Westem countries in successful development has been attributed to private individual initiatives rather than by the government. The case is buttressed in modem times because Japan and the newly industrializing countries of Asia, like South Korea, Singapore, Hong Kong and Taiwan have strong private enterprise economies. Third, is the overall poor performance of the economy since independence in 1957. The blame has often been laid at the door of nationalization, comprehensive planning and state control of the economy. 25 To remedy this, the expanding role of the state needs to be curtailed and much more of such activities entrusted to the private sector.

The main difficulty about privatization is its practicability, given the central role of the state in the Ghanaian economy since independence. The question is whether privatization would simply mean the replacement of a public sector monopoly by a private sector one. If privatization is undertaken the enterprises in question would be sold to foreign interests, because the private indigenous sector does not have the capital and is not sufficiently organized to secure funds from local banks who demand collateral and charge exorbitantly high interest rates. Since there is a lack of private investors, privatization may mean the "internationali-

23 Republic of Ghana 1987, p. 8.

24 Republic of Ghana, Divestiture of Selected State-owned Enterprises in Ghana: Invitation to interested Investors, Accra 1988, p. 12-24.

25 Killick, op.cit. 
zation" of important sectors of the national economy. There is genuine fear among many Ghanaians that privatization could be the real beginning of "quantifiable neo-colonialism". Such suspicions have been exacerbated by the International Monetary Fund and World Bank's long standing preference for increasing the role of the private sector. these institutions lay down privatization as a policy condition for lending, in the same way that trade liberalization and devaluation are required. In fact, the economic recovery and structural adjustment programmes of the PNDC are being funded by these institutions contingent in part upon the implementation of the privatization policy.

Second, the PNDC has failed to realise the inadequacy of privatization as a panacea to improving the performance of state enterprises, by not learing from experience. For instance, after the overthrow of Nkrumah in 1966, the National Liberation Council govemment offered 30 state enterprises for sale. While only three found buyers, the rest were regarded as poor risks by the business community. Even the three which were bought were later on abandoned, because they could not be transformed into viable and profit-making enterprises.26 Again, Ghana's close neighbour, Togo which is one of the first African countries to travel the privatization route, has so far privatized one textile mill. The mill has been bought by overseas interests and is guaranteed the right to import raw materials and spare parts duty-free. The government has imposed a 4 per cent tariff on competitive imports and allowed the company running the mill to increase prices of the finished products as the price of raw material increases. In addition, the company has been given the best qualified senior management available in Togo. Even with all these advantages, it is not yet certain that the mill will be profitable. 27 What we want to argue is that even if enterprises have been privatized, there is no guarantee that they would turn out to become more profitable.

Third, the PNDC's privatization policy ignores the crucial fact that public ownership was in many cases prompted by the failure of the market, and the effective absence of willing and compatible private agents. State intervention in the economy was seen by Nkrumah and his Convention People's Party (CPP) as a means of reconciling their desire to modernize and develop the economy on the one hand, and to increase the degree of economic independence on the other. In the words of Killick:

in the absence of even the potential of a local entrepreneurial class to carry out industrialization at the speed Nkrumah wanted, reluctant as he was, in any case, to encourage the emergence of such a class, and deeply suspicious of foreign capital and other trappings of "neo-colonialism", there was a vacuum which the state was starred to fill. 28

27 Hirschoff, $R$., "The privatization drive" Af rica Report 1986, p. 89-92.

28 Killick, op.cit., p. 215. 
The massive public investments in infrastructure in Ghana during the Nkrumah era would never have been taken, for the simple reason that commercial returns on such investments were not attractive to the private sector. 29

The argument is often made that the pricate sector is more efficient than the public one and that profitability of state enterprises depends on the system of ownership. While this is a highly debatable viewpoint, the Ghanaian experience has shown that the private sector resorted to economic vices, like under-invoicing, over-invoicing, non-payment of tax, to "claim superiority over" the public sector. Ghamot group of companies, Kowus Motors and G.E. Amuah and Associates, only to mention a few, were confiscated by the AFRC because they had committed acts with a view of "sabotaging the economy" of Ghana. In other developing countries, like South Korea, Taiwan, Singapore and Hong Kong, experiences of state enterprises have shown that they achieved economic growth "not by regorously applying the tenets of textbook economics, but by combining major state intervention in economic areas".30 Haile-Mariam and Mengistu31 have emphasized that the superior economic performance of state enterprises in some developing countries - even when compared to that of private enterprises - points to the fact that there is no evidence to suggest that ownership systems have anybearing on profitability of enterprises.

Four, it seems the success stories concerning the privatization of state enterprises in the developed countries have marginal lessons for Ghana and other Third World countries. The reason is that many studies on privatization 32 focused attention on service enterprises rather than manufacturing ones. This raises two conceptual and operational problems. First, the effect of privatization on the profitability of manufacturing enterprises is not only uncertain but also unpredictable. As a result, the tranferability of the experience of developed countries to developing ones in privatization is questionable and untenable. 33 Second and more important in the case of service organizations, such as urban transportation where the comparative efficiency of the private sector is the greatest, the studies on privatization have failed to consider the inconsistent organizational objectives that state enterprises are expected to achieve. For instance, the Australian domestic airline industry "has always boomeranged between various political interests; and politicians have directed and mis-

29 Killick, op.cit.

30 Choksi, A., State Intervention in the Industrialization of Developing Countries: Washington DC: World Bank, 1979, p. 23.

31 Haile-Mariam, Y. and Mengistu, B., "Public enterprises and the privatization thesis in the third world", Third World Quarterly, 10 (1988), p. 1565-1587.

32 Gantt, A. and G. Dutto, Financial performance of govemment owned corporation in less developed countries, Intemational Monetary Fund, Washington DC, 1968; Ansari, J.A., Comparative Study Impact of Public and Private Manufacturing Sectors in Selected Developing Countries, Vienna, United Nations Industrial Development Organization (UNIDO), 1981; Nellis, J.R., Public Enterprises in sub-Saharan Africa, Washington DC: The World Bank, 1986; Hanke, S., "Strategies employed in successful privatization efforts", paper presented at the Intemational Conference on Privatization, sponsored by the US Agency for Intemational Development, Washington DC, 1986. Haile-Mariam and Megistu, op.cit. 
directed the activities of Britain's public corporations from their inception" ${ }^{34}$ It is therefore tempting to say that an enterprise which is supposed to perform multiple objectives will be less efficient than one which pursues clearly stated objectives of profit-making.

\section{Conclusion}

Is privatization a panacea for the dismal performance of state enterprises in Ghana? Certainly not. The generally poor financial performance of state enterprises in Ghana have been attributed to poor project planning, faulty selection of product lines, inadequate working capital and undues interference by the government in the control of managerial variables. 35 The solution for improving the profitability of state enterprises is to remove these contraints which militate against efficient operation. The solution lies in the formulation and implementation of policy changes and the development of effective managerial strategies, rather than change of ownership.

As this writer has argued elsewhere 36 , if state enterprises are to be viable, there is the need to recognize the fact that they respond to the facts of their existence and the imperatives built into their creation. A more pressing priority than privatization is an enquiry into the facts surrounding the existence of each state enterprise. Such an enquiry should concentrate on answering the following questions:

1. What exactly are the enterprises goals in real terms?

2. What specifially do the enterprises goals imply in terms of finance, manpower and time perspectives?

3. How do the costs of all kinds relate to the returns of all kinds in quantitative terms?

4. Is it necessary that the activity proposed be performed by a new state enterprise?37

The responsible ministries in consultation with the boards of state enterprises must determine and state as clearly as possible the objectives of state enterprises. If it could be possible, state enterprises should be insulated from being burdened with political or social objectives. Even when non-commercial obligations are imposed on enterprises, they should be as few as is consistent with their rationale. If the enterprises are made to understand that they should run strictly on commercial lines, then it is possible for them to make profits while at the same time satisfying broad socio-political objectives. In that case, adequate financial compensation should be made to the enterprises to offset the loss of income in

34 The Economist 1985, p. 72.

35 Pozen, op.cit.; Killick, op.cit.

36 Ayee, J. R. A., "Some Thoughts on the use fo the Profitability Criterion in Evaluating State Enterprises in Ghana", The Joumal of Management Studies, School of Administration, University of Ghana, Vol. 3 (1986) 3rd Series, p. 142-162.

37 Glentworth, G., "Public Enterprises in Developing Countries: Some Suggestions in Creation, Organization and Control", Joumal of Administration Overseas, 12 (1973), p. 190-205 (193). 
fulfilling the non-commercial socio-political objectives. ${ }^{38}$ Board of directors and managers of state enterprises should be given all the powers necessary to carry out their responsibilities. They should not only be limited to day-to-day affairs of the enterprises, but should also participate in policy formulation. Appointment of board members by the government should be made on the basis of expertise and competence rather than on the basis of political patronage. This would go in a long way to enhance the efficiency and despatch of the board in the handling of the enterprise's affairs.

Another policy option opened for the government to improve non-profitable state enterprises is for the govemment to tum them over to private management firms with the necessary expertise, while at the same time retaining full or partial ownership. The managing firm may be paid a percentage of the profit that the state enterprise makes. 39

It is our view that the privatization policy being pursued by the PNDC does not have the magic formula for increasing the viability of state enterprises. It must be pointed out that "it is not the size of the public sector or even the extent of its entervention that are at fault. It is rather the logic that shapes the decisions of politicians and administrators". 40

38 Akinsaya, op.cit.

39 Haile-Mariam and Mengistu, op.cit.

40 Sandbrook, R., The Politics of Africa's Economic Stagnation, Cambridge, 1985, p. 153. 


\title{
A Note on Privatization of State Enterprises in Ghana
}

\author{
By Joseph R.A. Ayee
}

Ghana's Provisional National Defence Council (PNDC) has resorted to the policy of privatization as an antidote to the dismal performance of state enterprises in the country. The article examines the privatization policy of the PNDC and argues that state intervention in the economy is justified and necessary. In the writer's view, privatization does not necessarily improve the viability of state enterprises, since it is fraught with numerous problems.

\section{The State Law and Urban Poverty in Tansania}

\section{By Joe L.P. Lugalla}

This paper is about the state, law and urban poverty in Tanzania. The paper examines how the state in Tanzania has been trying to solve the problem of urban poverty. The main argument is that the state's conception of urban poverty is not realistic. The urban poor are seen as responsible for their poverty. This is confirmed by the kind of coercive policies, legislation and other measures which have been instituted by the state in order to solve the problem. The paper argues that due to lack of a critical analysis of the causes of poverty, the state has been implementing policies which have exacerbated the problem, because they have treated the symptoms rather than the essential relations. The paper concludes by arguing that law, like other policies, has to assist the process of social and economic development. Rather than criminalizing the poor, in developing socialist countries like Tanzania law has to assist them.

\section{Property Rights and Agricultural Development. \\ The Land Issue in Equatorial Guinea}

\section{By Bernd Holznagel, Cord Jakobeit}

This paper illustrates the argument that land rights in Africa evolve in response to changing political, social and economic conditions. The case of Equatorial Guinea has more in common with the situation in other former Spanish colonies in America than with the typical African situation. A system of individual titles to the land, orderly registration and 